\title{
Species association in Xanthoceras sorbifolium Bunge communities and selection for agroforestry establishment
}

\author{
Qing Wang $\cdot$ Renbin Zhu $\cdot$ Jimin Cheng $\cdot$ Zhixiong Deng $\cdot$ Wenbin Guan • \\ Yousry A. El-Kassaby
}

Received: 24 August 2017/Accepted: 15 June 2018/Published online: 26 June 2018

(C) The Author(s) 2018

\begin{abstract}
We embraced the "learning from nature and back to nature" paradigm to develop viable agroforestry scenarios through studying species association in 12 wild yellowhorn (Xanthoceras sorbifolium: a Chinese endemic oil woody plants) communities. We identified 18 species combinations for their suitability as agroforestry mixes where positive associations were detected and thus economic benefits are anticipated. In each wild yellowhorn community, we use nonmetric multidimensional
\end{abstract}

Qing Wang and Renbin Zhu have contributed equally to this work.

Electronic supplementary material The online version of this article (https://doi.org/10.1007/s10457-018-0265-z) contains supplementary material, which is available to authorized users.

Q. Wang · Z. Deng · W. Guan $(\bowtie)$

School of Nature Conservation, Beijing Forestry

University, Beijing 100083, People's Republic of China

e-mail: swlab@bjfu.edu.cn

Q. Wang · Y. A. El-Kassaby ( $₫)$

Department of Forest and Conservation Sciences, Faculty of Forestry, The University of British Columbia,

Vancouver, BC V6T 1Z4, Canada

e-mail: y.el-kassaby@ubc.ca

R. Zhu

College of Resource and Environment, North West A\&F University, Yangling 712100, Shaanxi, People's Republic of China scaling ordination to assess community structure and composition, and the climatic variables that most likely influenced existing species distributions. Next, pairwise and multiple species associations were evaluated using several multiple species association indices (e.g., $\chi^{2}$, Jaccard, Ochiai, Dice). Generally, all species association indices were in agreement and were helpful in identifying several high valued medicinal species that showed positive and significant associations with yellowhorn. Finally, we proposed several agroforestry species mixes suitable for yellowhorn.

Keywords Xanthoceras sorbifolium - Species association and selection - Agroforestry mixes . Nonmetric multidimensional scaling ordination (NMDS)

\section{R. Zhu}

Xishuangbanna Tropical Botanical Garden, Chinese Academy of Sciences, Menglun 666303, Yunnan, People's Republic of China

J. Cheng

Institute of Soil and Water Conservation, Chinese Academy of Sciences and Ministry of Water Resources, Yangling 712100, Shaanxi, People's Republic of China 


\section{Introduction}

Plant communities' structure, composition, and environmental covariates represent the three fundamental objects that have received substantial ecological attention for more than a century (Adler and HilleRisLambers 2008). Recent research findings indicate that the on-going climate change has influenced these ecological objects (Malanson 2017) and highlighted the role of species- climate variances relationship and more specifically the identification of which climate variances significantly affect particular species fitness (de Gasper et al. 2015; Šímová et al. 2015). However, plant-plant relationship has also been proven to be effective in shaping community composition through influencing landscape-scale productivity or species relative distribution in a more substantial ways than the climate change's short term effects (Dohn et al. 2013; Riginos 2009).

Evaluating species association could help understanding the various relationships among species (positive or negative) as well as providing insights on community's structure and dynamic under climate change. Species association is usually shaped by the differences in community habitat affecting species' distribution (i.e., the spatial arrangement of a biological taxon) (Greig-Smith 1983). Positive species association may exists when one species relies on another or when both species are affected by the same bioclimatic or no-bioclimatic factors, while negative association is triggered by competition over space, nutrition, allele-chemical interaction, or demand of different environment (shade or light preference). The majority of research on species association has focus on community structure (Masaki et al. 1992; Tokeshi 1993; Wilson et al. 1995); however, the literature lacked its possible role on modern agroforestry establishment (management system that combines trees and crops for the creation of diverse, sustainable, and ecologically sound land use). Modern agroforestry should be designed to minimize interspecific competition and maximize benefits, so it can provide ecosystem services and economic commodities. The Millennium Ecosystem Assessment (Assessment 2005) and the International Assessment of Agricultural Science and Technology for Development (IAASTD) (Kiers et al. 2008) recognized the benefits of modern agroforestry while considering the tradeoff between landowners/farmers and environmental services (Schmidhuber and Tubiello 2007). Deeper understanding of species association may provide a workable model for the development and establishment of new agroforestry assembles through the proper selection of compatible species combinations (Jose 2009; Jose et al. 2004).

Xanthoceras sorbifolium Bunge (yellowhorn), a relic oil woody plants that is endemic to China (Yang et al. 2005). Due to its high oil content and economic importance, yellowhorn has received increased scientific and managerial attention with extensive studies covering its genetics (Bi and Guan 2014), physiology (Zhou et al. 2012; Zhou and Liu 2012), industrial and medicinal uses (Ma et al. 2004). Knowledge on wild yellowhorn communities' structures are very scant and mainly remain unknown. Here, we studied 12 wild yellowhorn communities to: (1) evaluate the species community composition in relation to climatic variables, (2) uncover the understory species associations with special reference to woody and herbaceous species, and (3) develop a yellowhorn agroforestry plantation mixture resembling those present in wild communities.

\section{Materials and methods}

Study area

The present study was carried out between July 2014 and June 2015 and covered 12 yellowhorn communities in northern China, representing 12 counties in 6 provinces (Shaanxi, Shanxi, Ningxia, Gansu, Qinghai, and Hebei) (Table 1). The ecology of this region is characterized as arid to semi-arid with $300-600 \mathrm{~mm}$ rainfall with $90 \%$ occurring between July and September (Kimura et al. 2007; Xin et al. 2011). July and January mean temperatures are $17{ }^{\circ} \mathrm{C}$ and $-5{ }^{\circ} \mathrm{C}$, respectively (Maher 2016).

\section{Data collection}

The 12 yellowhorn communities were investigated by line transects. In each location, a randomly located plot of $3000 \mathrm{~m} \times 10 \mathrm{~m}$ was studied (36 ha in total). The minimum distance separating any two sampling plots was $11.5 \mathrm{~km}$. All woody and herbaceous species within each plot were recorded, and included 52 woody and 97 herbaceous species; however, 100 
Table 1 Summary of the twelve locations along with their locations (Lat., Long., Elev.), canopy coverage, soil texture, and slope

\begin{tabular}{|c|c|c|c|c|c|c|c|}
\hline & Location & $\begin{array}{l}\text { Latitude } \\
\left({ }^{\circ} \mathrm{N}\right)\end{array}$ & $\begin{array}{l}\text { Longitude } \\
\left({ }^{\circ} \mathrm{E}\right)\end{array}$ & $\begin{array}{l}\text { Elevation } \\
(\mathrm{m})\end{array}$ & $\begin{array}{l}\text { Canopy } \\
\text { coverage }(\%)\end{array}$ & $\begin{array}{l}\text { Soil } \\
\text { texture }\end{array}$ & $\begin{array}{l}\text { Slope } \\
\left({ }^{\circ}\right)\end{array}$ \\
\hline 1 & $\begin{array}{l}\text { Xifeng District, Qingyang City, Gansu } \\
\text { Province }\end{array}$ & $35^{\circ} 40^{\prime} 35.39^{\prime \prime}$ & $107^{\circ} 29^{\prime} 37.96^{\prime \prime}$ & 1120 & 5 & $\begin{array}{l}\text { Typical } \\
\text { loess }\end{array}$ & 40 \\
\hline 2 & $\begin{array}{l}\text { Heshui County, Qingyang City, Gansu } \\
\text { Province }\end{array}$ & $36^{\circ} 04^{\prime} 56.54^{\prime \prime}$ & $108^{\circ} 19^{\prime} 42.22^{\prime \prime}$ & 1360 & 20 & $\begin{array}{c}\text { Typical } \\
\text { loess }\end{array}$ & 20 \\
\hline 3 & $\begin{array}{l}\text { Yu County, Zhangjiakou City, Hebei } \\
\text { Province }\end{array}$ & $40^{\circ} 05^{\prime} 41.69^{\prime \prime}$ & $115^{\circ} 03^{\prime} 24.57^{\prime \prime}$ & 1186 & 10 & $\begin{array}{c}\text { Typical } \\
\text { loess }\end{array}$ & 15 \\
\hline 4 & $\begin{array}{l}\text { Pingluo County, Shizuishan City, } \\
\text { Ningxia Province }\end{array}$ & $38^{\circ} 53^{\prime} 24.75^{\prime \prime}$ & $106^{\circ} 07^{\prime} 15.11^{\prime \prime}$ & 1461 & 5 & $\begin{array}{l}\text { Sierozem } \\
\text { soil }\end{array}$ & 35 \\
\hline 5 & $\begin{array}{l}\text { Xunhua County, Haidong City, Qinghai } \\
\text { Province }\end{array}$ & $35^{\circ} 49^{\prime} 47.87^{\prime \prime}$ & $102^{\circ} 41^{\prime} 34.39^{\prime \prime}$ & 1961 & 10 & $\begin{array}{l}\text { Typical } \\
\text { loess }\end{array}$ & 30 \\
\hline 6 & $\begin{array}{l}\text { Fangshan County, Luliang City, Shanxi } \\
\text { Province }\end{array}$ & $37^{\circ} 52^{\prime} 44.03^{\prime \prime}$ & $111^{\circ} 14^{\prime} 46.00^{\prime \prime}$ & 1219 & 20 & $\begin{array}{l}\text { Typical } \\
\text { loess }\end{array}$ & 25 \\
\hline 7 & $\begin{array}{l}\text { Ji County, Lingfen City, Shanxi } \\
\text { Province }\end{array}$ & $36^{\circ} 09^{\prime} 31.26^{\prime \prime}$ & $110^{\circ} 41^{\prime} 14.53^{\prime \prime}$ & 1086 & 40 & $\begin{array}{c}\text { Typical } \\
\text { loess }\end{array}$ & 40 \\
\hline 8 & $\begin{array}{l}\text { Shilou County, Luliang City, Shanxi } \\
\text { Province }\end{array}$ & $37^{\circ} 01^{\prime} 16.96^{\prime \prime}$ & $110^{\circ} 44^{\prime} 51.40^{\prime \prime}$ & 1085 & 10 & $\begin{array}{l}\text { Typical } \\
\text { loess }\end{array}$ & 15 \\
\hline 9 & $\begin{array}{l}\text { Tianlong Mountain, Taiyuan City, } \\
\text { Shanxi Province }\end{array}$ & $37^{\circ} 42^{\prime} 33.83^{\prime \prime}$ & $112^{\circ} 23^{\prime} 38.66^{\prime \prime}$ & 973 & 50 & $\begin{array}{r}\text { Clayey } \\
\text { loess }\end{array}$ & 25 \\
\hline 10 & $\begin{array}{l}\text { Fanzhi County, Yizhou City, Shanxi } \\
\text { Province }\end{array}$ & $39^{\circ} 13^{\prime} 24.83^{\prime \prime}$ & $113^{\circ} 17^{\prime} 13.29^{\prime \prime}$ & 1026 & 5 & $\begin{array}{l}\text { Sandy } \\
\text { loess }\end{array}$ & 15 \\
\hline 11 & $\begin{array}{l}\text { Ganquan County, Yan'an City, Shaanxi } \\
\text { Province }\end{array}$ & $36^{\circ} 14^{\prime} 51.45^{\prime \prime}$ & $109^{\circ} 20^{\prime} 49.65^{\prime \prime}$ & 1060 & 20 & $\begin{array}{c}\text { Typical } \\
\text { loess }\end{array}$ & 20 \\
\hline 12 & $\begin{array}{l}\text { Feng County, Baoji City, Shaanxi } \\
\text { Province }\end{array}$ & $34^{\circ} 03^{\prime} 44.94^{\prime \prime}$ & $106^{\circ} 41^{\prime} 39.70^{\prime \prime}$ & 1123 & 60 & $\begin{array}{r}\text { Clayey } \\
\text { loess }\end{array}$ & 25 \\
\hline
\end{tabular}

species were removed from the analysis (see below) (Table S1). For each plot, a total of 188 climatic variables representing the prevailing climatic conditions present during the surveys were generated by estimating climate norms from geographic coordinates using the software package Climate AP (Wang et al. 2016).

Data analysis

For species association analyses, 100 of the 149 species occurred only in a single plot (i.e., singletons), and were excluded, thus the subsequent analyses were based on the remaining 49 species (5 annual or biennial forb, 25 perennial forb, and 19 woody species, Table S1). Additionally, we compared the species' lists between the May and September/October surveys and did not detect any incidence of presence/absence across the 12 studied plots, indicating that life-history differences (seasonal effects) did not play a role in the observed species.

Ordination analysis between species and climate variance

The Nonmetric Multidimensional Scaling (NMDS) technique which is known to be effective with ordination when compared to other multivariate techniques in handling ecological data (Bettinetti et al. 2000; Kenkel and Orlóci 1986) was used and implemented in R "Vegan" package to interpret the relationship between species (dependent variables) and climatic variables (Oksanen et al. 2013).

Multi-species associations

Multi-species associations were carried out in $\mathrm{R}$ "spaa" package (Griffith et al. 2016). We first 
consider measures of species association (SA) based on records of presence or absence only.

Variance of species relative frequency

$\sigma_{T}^{2}=\sum_{i=1}^{S} P_{i}\left(1-P_{i}\right)$

where $P_{i}$ is species frequency, then variance of species number was estimated as:

$S_{T}^{2}=(1 / N) \sum_{j=1}^{N}\left(T_{j}-t\right)^{2}$

where $N$ is the number of plots (12), $S$ is number of species (49), $T_{j}$ is the total number of species for each plot, and $t$ is the variance of species relative frequency.

Species relative frequency was determined as:

$P_{i}=\frac{n_{i}}{N}$

where $n_{i}$ is the total number of species for plot $i$.

Variance ratio (VR) is expressed as:

$V R=\frac{S_{T}^{2}}{\sigma_{T}^{2}}$

where positively and negatively associated species produce VR values of $>1$ and $<1$, respectively.

The value $W$ is equivalent to Chi-square $\left(\chi^{2}\right)$ with $n$ degrees of freedom:

$W=V R * N$

If $\boldsymbol{\chi}_{0.05}^{2}(\boldsymbol{N})>\boldsymbol{W}>\boldsymbol{\chi}_{0.95}^{2}(\boldsymbol{N}), \quad$ species $\quad$ were independent.

\section{Pairwise species associations}

Numerous methods of expressing the degree of association between species have been proposed and used. In fact the data represent a simple $2 \times 2$ contingency table, and the association measure of such tables has been used to address completely different contexts ( $\mathrm{Li}$ et al. 2008). For any two species, these measures may be expressed in the form where the total number of samples $\mathrm{M}$, is partitioned into those with: both species present (a), both species absent (d), and only one of the two species present (b and c). Pairwise species associations were implemented in R "spaa" package (Griffith et al. 2016; Zhang 2013).

The value $V$ is used to determine if any pair of species are positively or negatively associated:

$V=\frac{(a+b)-(b+c)}{a+b+c+d}$

where $a, b, c$, and $d$ represent the two species possible scenarios (above) and values of $>0.0$ or $<0.0$ represent positive and negative associations, respectively.

The Chi-square (Yate's correction) is used to determine the two species association significance level:

$\chi^{2}=\frac{(|a d-b c|-0.5 N)^{2} N}{(a+b)(a+c)(b+d)(c+d)}$

with $\quad \boldsymbol{\chi}^{2} \geq 3.841(0.01<\boldsymbol{P}<0.05) \quad$ and $\chi^{2} \geq 6.635(P<0.01) \quad$ indicating, significant and highly significant pairwise association between the two species means.

The following three indices were also used for assessing species association:

1. The Jaccard index (JI) (Hubalek 1982). It is a presence-absence metric, which indicates quantitative species abundance, and contains important information about species-species interactions (Jost 2007):

$J I=\frac{a}{a+b+c}$

2. To evaluate the species association in a given region is best using the Ochiai index $(O I)$, as it can be split into the phi coefficient of association and species regional diagnostic value (De Cáceres et al. 2008). $O I$ is very strongly correlated with the Dice index (Hubalek 1982).

$O I=\frac{a}{\sqrt{(a+b)(a+c)}}$

3. Dice (1945) (Dice index; DI) developed coincidence index from a simpler metric (Dice 1945), which is 'association index', and conceptually equivalent to measuring the 'degree of faunal resemblance' between continental biotas developed by George G. Simpson (Arita 2017; Simpson 1943). 


$$
D I=\frac{2 a}{2 a+b+c}
$$

The $J I, O I$, and $D I$ indices show the percentage of co-occurrence and its associated level, when $\mathrm{a}=0.0$, $J I, O I$, and $D I$ yield a value of zero indicating that the two species never co-occurred and when $\mathrm{a}=1$ indicate the two species co-occurred.

Association Coefficient $(A C)$ :

If $a b \geq b c$, then $A C=\frac{a d-b c}{(a+b)(b+d)}$

If $b c>a d$ and $d \geq a$, then $A C=\frac{a d-b c}{(a+b)(a+c)}$

If $b c>a d$ and $d<a$, then $A C=\frac{a d-b c}{(b+d)(d+c)}$

$A C$ ranges from 1 (in the case of perfect positive association) to 0.0 or -1 (in the case of perfect negative association). When $A C=0.0$, species were independent. The same applied for point correlation coefficient (PCC) and Pearson correlation.

Point correlation coefficient (PCC):

$P C C=\frac{a d-b c}{(a+b)(a+c)(c+d)(b+d)}$

Pearson correlation:

$r_{p}=\frac{\sum_{i=1}^{N}\left(x_{i}-\bar{x}\right)\left(y_{i}-\bar{y}\right)}{\sqrt{\sum_{i=1}^{N}\left(x_{i}-\bar{x}\right)^{2} \sum_{i=1}^{N}\left(y_{i}-\bar{y}\right)^{2}}}$

where $x_{i}$ and $y_{i}$ represent the species number of $x$ and $y$ in plot $i$; and $\bar{x}, \bar{y}$ represent the average species number in all plots.

\section{Results}

Communities' component and ordination

A total of 49 species ( 5 annual or biennial forb, 25 perennial forb, and 19 woody species) belonging to 41 genera in 24 families were recorded in the studied 12 plots (Table S1). The species with the most occurrence belonged to four families; namely, Asteraceae (11 species), Poaceae (5 species), Fabaceae (3 species), and Rosaceae (3 species) (Table S1).

The nonmetric multidimensional scaling technique (NMDS) showed that MAP (mean annual precipitation $\left.(\mathrm{mm})\left(\mathrm{r}^{2}=0.72, P=0.004\right)\right)$, AHM (annual heat: moisture index (MAT +10$) /($ MAP/1000)) $\left.\left(\mathrm{r}^{2}=0.85, P=0.001\right)\right)$, CMD (Hargreaves climatic moisture deficit $\left.\left(\mathrm{r}^{2}=85, \quad P=0.001\right)\right), \quad$ PРT09 (September precipitation $\left.\left(\mathrm{r}^{2}=0.45, P=0.001\right)\right)$, and TD (temperature difference between MWMT and MCMT, or continentally $\left.\left({ }^{\circ} \mathrm{C}\right)\left(\mathrm{r}^{2}=0.48, D I=0.050\right)\right)$ were significantly affected the distribution of herbaceous plants (Fig. 1a). While EMT (extreme minimum temperature over 30 years $\left(\mathrm{r}^{2}=0.57\right.$, $P=0.028)$ ), Tmin_DJF (winter mean minimum temperature $\left.\left({ }^{\circ} \mathrm{C}\right)\left(\mathrm{r}^{2}=0.68, P=0.009\right)\right)$, DD_0_MAM (spring degree-days below $0{ }^{\circ} \mathrm{C} \quad\left(\mathrm{r}^{2}=0.82\right.$, $P=0.001)$ ), PAS_SON (autumn precipitation as snow $\left.\left(\mathrm{r}^{2}=0.62, P=0.004\right)\right)$ and PAS11 (November precipitation as snow $\left.\left(\mathrm{r}^{2}=0.63, P=0.003\right)\right)$ significantly affected the distribution of woody plants (Fig. 1b).

Species association among the 49 species

The variance ratio $(V R)$ of herbaceous multi-species association for the 12 plots was equal to 1.784 , a value $>1$ with $W=21.407\left(\chi_{0.995}^{2}(49)=27.249\right)$, indicating that they were positively correlated. The pairwise species associations produced a total of 1176 pairwise associations involving 49 pairwise herbaceous species with 18 significant $\left(\chi^{2}>3.841\right)$ (Table 2$)$. The 18 significant pairwise associations were Androsace longifolia and Artemisia frigida, Androsace longifolia and Scutellaria viscidula, Androsace longifolia and Ephedra sinica, Androsace longifolia and Ulmus macrocarpa, Artemisia capillaris and Cymbaria mongolica, Artemisia frigida and Ephedra sinica, Artemisia frigida and Scutellaria viscidula, Artemisia frigida and Ulmus macrocarpa, Convolvulus ammannii and Cynanchum thesioides, Convolvulus ammannii and Ulmus glaucescens, Cynanchum thesioides and Ulmus glaucescens, Ephedra sinica and Scutellaria viscidula, Ephedra sinica and Ulmus macrocarpa, Leymus secalinus and Thermopsis lanceolata, Lonicera ferdinandi and Rosa xanthina $f$. normalis, Saussurea japonica and Sophora davidii, Scutellaria viscidula and Ulmus macrocarpa, and Stipa bungeana and 
Fig. 1 Nonmetric multidimensional scaling (NMDS) ordination of herbaceous (a) and woody (b) species based on the Bray-Curtis dissimilarity of community composition (stress

(herbaceous) $=0.080$, stress $($ woody $)=0.008)$. Stress values of $\leq 0.1$ and $\leq 0.05$ are considered fair and good fit, respectively) represented the best ordination space fit $\left(\mathrm{R}^{2}\right.$ (herbaceous) $=0.970$, $\mathrm{R}^{2}($ woody $\left.)=0.974\right)$. The circles and numbers indicate the 12 communities and the arrows show the direction at which the climatic vectors fit the best (using envfit. function) onto the NMDS ordination space. Only climatic factors reach significant levels $(P<0.05)$ are represent

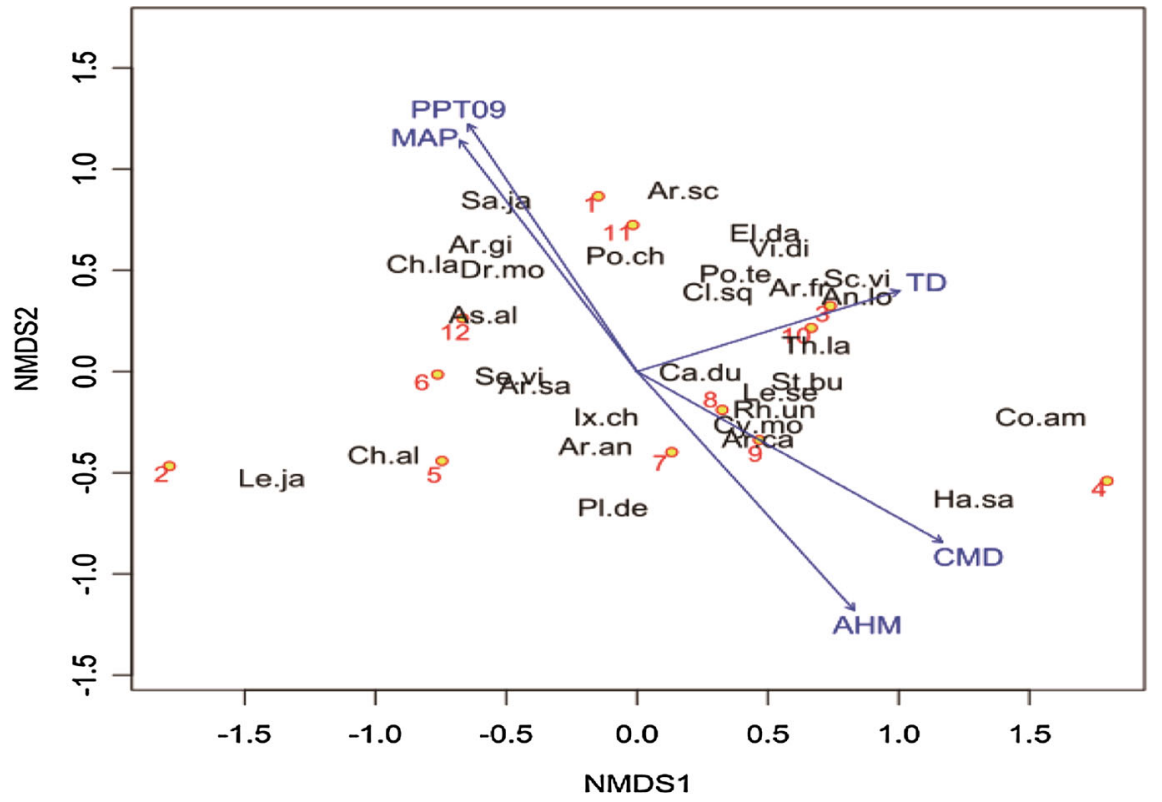

(a)

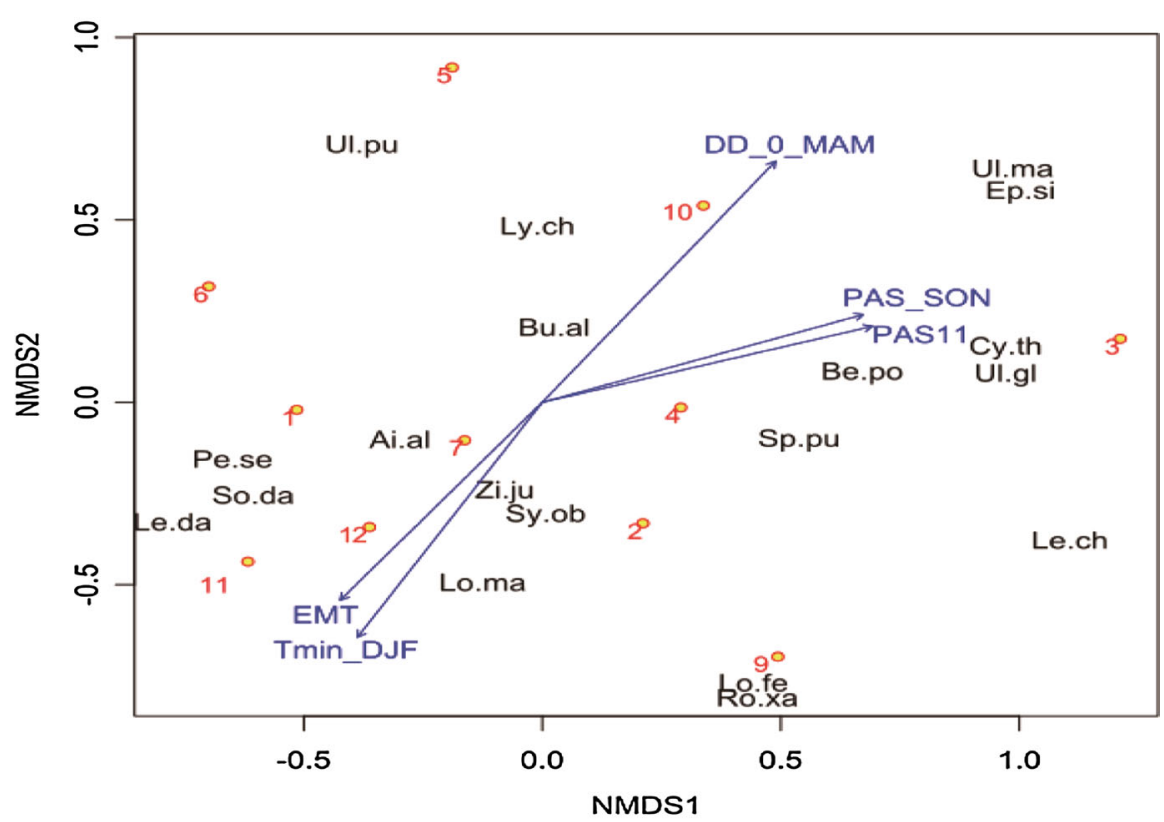

(b)
Thermopsis lanceolata. The $V$ value was used to determine if these pairwise were positively or negatively associated and yielded 896 (76.19\%) and 113 $(9.61 \%)$ pairwise positive and negative associations, respectively. The other pairwise association indices produced a slight progression of a declining values with $O I>D I>J I$ and all were consistent and produced supporting results (Fig. 2, Table 2 and Table S2). Ochiai index (OI) produced 47 strong positively pairwise associations (OI $>0.8$, Fig. 2, Table 2 and Table S2). Similarly, the point correlation coefficient (PCC), Pearson correlation, and $A C$ were mostly similar, supporting the results obtained from the $O I, D I$, and $J I$ indexes (Table 2). 
Table 2 Summary of the eight association indices for the observed 18 significant species pairwise associations

\begin{tabular}{|c|c|c|c|c|c|c|c|c|c|}
\hline Species pairwise association $^{\dagger}$ & Chi-square $^{\S}$ & V & Ochiai & Dice & Jaccard & Pearson & Spearman & PCC & $\mathrm{AC}$ \\
\hline Artemisia capillaris-Cymbaria mongolica & $7.92 * *$ & 1 & 1 & 1 & 1 & 1 & 1 & 0.03 & 1 \\
\hline Androsace longifolia-Artemisia frigida & $5.88^{*}$ & 1 & 1 & 1 & 1 & 1 & 1 & 0.05 & 1 \\
\hline Androsace longifolia-Ephedra sinica & $5.88^{*}$ & 1 & 1 & 1 & 1 & 1 & 1 & 0.05 & 1 \\
\hline Androsace longifolia-Scutellaria viscidula & $5.88^{*}$ & 1 & 1 & 1 & 1 & 1 & 1 & 0.05 & 1 \\
\hline Androsace longifolia-Ulmus macrocarpa & $5.88^{*}$ & 1 & 1 & 1 & 1 & 1 & 1 & 0.05 & 1 \\
\hline Artemisia frigida-Ephedra sinica & $5.88^{*}$ & 1 & 1 & 1 & 1 & 1 & 1 & 0.05 & 1 \\
\hline Artemisia frigida-Scutellaria viscidula & $5.88^{*}$ & 1 & 1 & 1 & 1 & 1 & 1 & 0.05 & 1 \\
\hline Artemisia frigida-Ulmus macrocarpa & $5.88^{*}$ & 1 & 1 & 1 & 1 & 1 & 1 & 0.05 & 1 \\
\hline Convolvulus ammannii-Cynanchum thesioides & $5.88^{*}$ & 1 & 1 & 1 & 1 & 1 & 1 & 0.05 & 1 \\
\hline Convolvulus ammannii-Ulmus glaucescens & $5.88^{*}$ & 1 & 1 & 1 & 1 & 1 & 1 & 0.05 & 1 \\
\hline Cynanchum thesioides-Ulmus glaucescens & $5.88^{*}$ & 1 & 1 & 1 & 1 & 1 & 1 & 0.05 & 1 \\
\hline Ephedra sinica-Scutellaria viscidula & $5.88^{*}$ & 1 & 1 & 1 & 1 & 1 & 1 & 0.05 & 1 \\
\hline Ephedra sinica-Ulmus macrocarpa & $5.88^{*}$ & 1 & 1 & 1 & 1 & 1 & 1 & 0.05 & 1 \\
\hline Lonicera ferdinandi-Rosa xanthina & $5.88^{*}$ & 1 & 1 & 1 & 1 & 1 & 1 & 0.05 & 1 \\
\hline Saussurea japonica-Sophora davidii & $5.88^{*}$ & 1 & 1 & 1 & 1 & 1 & 1 & 0.05 & 1 \\
\hline Scutellaria viscidula-Ulmus macrocarpa & $5.88^{*}$ & 1 & 1 & 1 & 1 & 1 & 1 & 0.05 & 1 \\
\hline Leymus secalinus-Thermopsis lanceolata & $4.50^{*}$ & 0.83 & 0.87 & 0.86 & 0.75 & 0.82 & 0.82 & 0.03 & 1 \\
\hline Stipa bungeana-Thermopsis lanceolata & $4.50^{*}$ & 0.83 & 0.87 & 0.86 & 0.75 & 0.82 & 0.82 & 0.03 & 1 \\
\hline
\end{tabular}

${ }^{\dagger}$ Significant pairwise associations, other non-significant pairwise associations are listed in supplemental Table S2

${ }^{\S}$ Significant level: $* P<0.05 ; * * P<0.01$

\section{Discussion}

Species component and response to different climatic variables

Climatic variables have significant effect on plant species communities by directly changing species interactions leading to communities' structure changes (Malanson et al. 2017; Tilman et al. 2001). The present study indicated that herbaceous species response to annual climatic variables (TD, MAP, AHM, CMD, PPT09) was stronger than woody species, especially annuals and biannual (mostly herbaceous species) (Dwyer et al. 2015; Koerner and Collins 2014). Our results is in agreement with previously published on herbaceous plants sensitivity to water resources (e.g., Microlaenastipoides Labil, Cymbopogon refractus: Pathare et al. 2017) and temperature (e.g., Aciphylla glacialis: Briceño et al. 2014). The observed difference between woody and herbaceous species could be due to the former slower migration rate as compared to the latter, thus creating a climate change response lag for woody species (Adler and HilleRisLambers 2008; Lenoir and Svenning 2015; Yamori et al. 2014). It is noteworthy to mention that the climate change impact is long-term in nature and the apparent contemporary ability of some woody species to withstand drought (e.g., Pseudotsuga menziesii: Bansal et al. 2015); yellowhorn: Ruan et al. 2017) or tolerance to low temperature (e.g., white spruce: Liu et al. 2015) is bound to climatic variables. Based on the NMDS analysis, the fact that herbaceous and woody species response differently to climatic variables hints to the ability of herbaceous-herbaceous species relationship to explain the short-term community composition changes associated with climatic variables variation while woody-woody species relationship explain those changes associated with long-term effects of climatic variables (i.e., changes in plant communities structure and composition are indicators of climatic variables). Thus, the major crop mix with woody species should consider the prevailing climatic variables as long-term plan (mapping the suitable area for the selected woody species), while mix plantation with herbaceous should be consider climatic variables to selected 
Fig. 2 Lower semi matrix of the Ochiai index (OI) showing 1176 pairwise species relationship. Filled circle, filled triangle, filled square, open circle, open square, and open diamond represent OI values of $>0.83,0.67-0.83$, $0.50-0.67,0.33-0.50$, $0.17-0.33$, and $<0.17$, respectively. Filled circle is the only pairwise maybe considered for yellowhorn agroforestry (see Table S1 for species number)

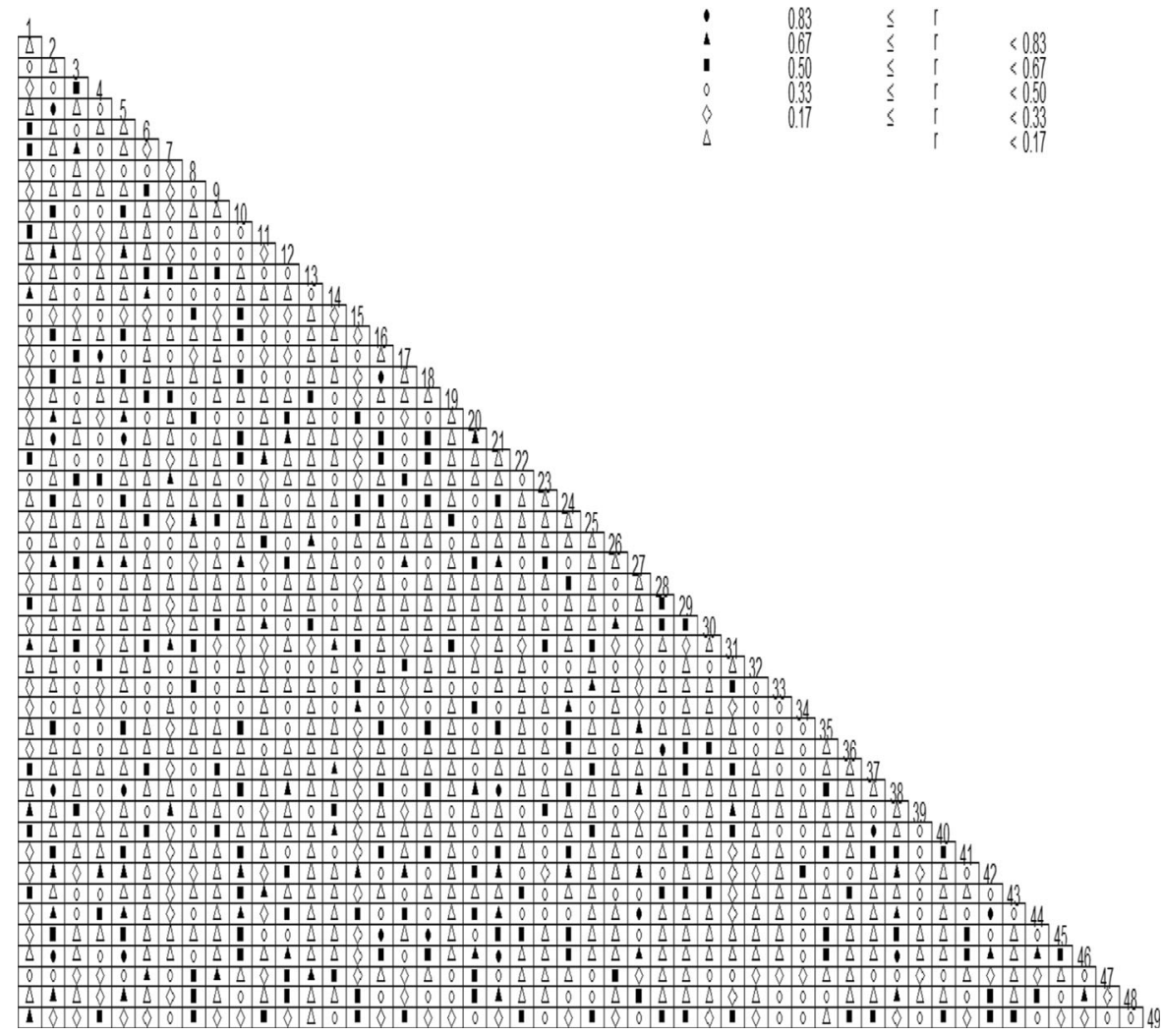

suitable species in different locations (i.e., species have drought tolerance may be selected for dry area).

Species association and species combination selection in yellowhorn communities

Positive species relationship plays an important role in their communities composition no matter if it is highly variable (Dullinger et al. 2007) or even non-significant (Mitchell et al. 2009). Research found that the growth rates of woody plants were highly relative to their conspecific versus heterospecific neighbors (Dohn et al. 2017). Our results indicated that both woody and herbaceous species showed multi-species positive associations in yellowhorn communities as all pairwise species association indexes $\left(\chi^{2}, V, \mathrm{AC}, P C C\right.$, Jaccard $(J I)$, Ochiai $(O I)$, and Dice $(D I)$ ) were in agreement and supported each other and significant positive associations among economically valuable species were observed (e.g., Artemisia capillaris, Artemisia frigida, Scutellaria viscidula, Thermopsis lanceolate, Ephedra sinica, and Rosa xanthina) in the studied yellowhorn wild communities (Table 2).
These positive associations could be considered for species combination selection in yellowhorn's agroforestry mixes.

Recently evidence of positive beneficial species interactions in plant communities has been recognized and reported (Kuebbing and Nuñez 2015). Such beneficial interactions could be facilitated through improving nutrient availability to a species' contemporary associates or elevating stress in harsh environments such as salt marches, and deserts and arctic regions (Blaser et al. 2013; Callaway et al. 1991; Chapin et al. 1994; Franco and Nobel 1989). For example, a reciprocal beneficial relationship was observed for an agroforestry mix consisting of planting the leguminous shrub Retama sphaerocarpa with the Marrubium vulgare understory (Pugnaire et al. 1996). Furthermore, this observed beneficial relationship was not realized if Retama sphaerocarpa and Marrubium vulgare were individually planted (Pugnaire et al. 1996). Nitrogen has a significant positive effect on yellowhorn root, stem, and leaf development and most importantly improving seeds production (Wei et al. 2010). Members of the Fabaceae family are 
known for their biological nitrogen fixation. Sophora davidii and Thermopsis lanceolata are members of the Fabaceae family and have shown positive association in the studied 12 yellowhorn communities. In addition to Sophora davidii and Thermopsis lanceolata nitrogen fixing abilities, which is beneficial to yellowhorn, they have proven medicinal values (Ciğerci et al. 2016; Sheela et al. 2006), representing an ideal agroforestry mix. The combinations of Sophora davidii or Thermopsis lanceolata and yellowhorn represent promising agroforestry scenarios. It is well known that Artemisia capillaris, Leymus secalinus and Stipa bungeana are widely distributed on the Loess Plateau (Guo et al. 2006), a situation that make Sophora davidii and Thermopsis lanceolata readily adapted to the environment. Sophora davidii has been successfully cultivated in Nei-Meng-gu region of China for many years (Guo et al. 2014), thus it should be consider as a feasible understory species with yellowhorn in agroforestry plantations.

Tree and shrub/herb mixes (e.g., multi-species agroforestry) are among the most common agroforestry combinations as they take full use of their spatial environment, including access to sunlight. For example, root crops, legumes, sweet sorghum, and other biofuels crops are successfully used as the intercrop with mango (Mangifera indica) and cassava (Manihot esculenta) (Harrison 2005; Harrison and Harrison 2016; Harrison et al. 2009)). Additional herbaceous and small shrub species such as Scutellaria viscidula, Ephedra sinica, and Rosa xanthine are wellknown for their medicinal (traditional Chinese medicine, Table 3) (Efferth and Kaina 2011; Ekor 2013), and nutritional and perfume extracts values (De Padua et al. 1999). Yellowhorn agroforestry understory species could consider combining Scutellaria viscidula and Ephedra sinica or Rosa xanthine, which maximize the full use of the available resources. However, Ephedra sinica and Rosa xanthine were negitively associated, thus their co-planting should be avioded. The combination of Lonicera ferdinandi and Rosa xanthine is also recommended as they are positively associated pair (Fig. 2, Table 2 and Table S2).

Oil uses agroforestry demonstration sites including Paeibua suffruticosa and yellowhorn have been recently established in Shandong Provence China (PY, personal observation). However, yellowhorn multi-species agroforestry still needs further exploration as basic questions such as understory species selection, timing of different species planting, and intercrop distance have not fully investigated (Dick et al. 2011).

Sustainable management and mix agroforestry in yellowhorn communities

The increasing demand for forest products, including biofuel, has caused a rapid exploitation of forests resulting in substantial loss of biodiversity (Amigun et al. 2011). The development of innovative management systems that balance environmental and economic concerns while maintaining the sustainable use of the resources, especially for private and small landowners, are of substantial values. Agroforestry offers an opportunity for optimum forest utilization while maintaining biodiversity through the efficient use of underutilized resources existing in major forest tree stands/populations (Tamang et al. 2014). Yellowhorn has been recognize as one of the nextgeneration biofuel species in China (Zhang et al. 2010), thus it's over exploitation is of concern. The sustainable management of yellowhorn in its "close to nature" communities is a favorable scenario to forest owners and ecologist. The development of viable yellowhorn agroforestry mixes that capitalizes on the positive and significant species associations is urgently needed; however, this "new concept" is costly, not commonly practiced, and more importantly without demonstrable economic success. The present study has identified several yellowhorn and herbaceous and small shrub species positive and significant associations that could be translated to agroforestry mixes. These selections represent a "learning from nature and back to nature" paradigm, with species selections that is adapted to local climatic or bioclimatic variables as well as a prerequisite for designing conservational practices. In our opinion, future agroforestry practices should consider combining of community ecology, species associations, species distributions, climate change, and economic benefits.

\section{Conclusions and future of work}

Species screening for agroforestry is often time- and resources-dependent. Species association analyses are widely used in ecological studies and may provide an 
Table 3 Species with medical use for the selected for yellowhorn agroforestry

\begin{tabular}{|c|c|c|}
\hline Species & Medical values & References \\
\hline $\begin{array}{l}\text { Artemisia } \\
\text { capillaris }\end{array}$ & $\begin{array}{l}\text { Remedy liver diseases such as hepatitis, jaundice and fatty liver in traditional oriental } \\
\text { medicine }\end{array}$ & Yeo et al. (2018) \\
\hline $\begin{array}{l}\text { Artemisia } \\
\text { frigida }\end{array}$ & Pharmacological functions of stanch and detumescence & $\begin{array}{l}\text { Liu et al. (2013) and } \\
\text { Yang et al. (2006) }\end{array}$ \\
\hline $\begin{array}{l}\text { Cymbaria } \\
\text { mongolica }\end{array}$ & Compounds exhibit significant antitumor and antibacterial activity & $\begin{array}{l}\text { Dai et al. (2002) and } \\
\text { Wang et al. (2012) }\end{array}$ \\
\hline $\begin{array}{c}\text { Cynanchum } \\
\text { thesioides }\end{array}$ & Used for lungs; relive pain & Tan (2012) \\
\hline Ephedra sinica & Reduce obesity and hyperglycemia & $\begin{array}{l}\text { Song et al. (2012) and } \\
\text { Zhao et al. (2009) }\end{array}$ \\
\hline $\begin{array}{l}\text { Leymus } \\
\text { secalinus }\end{array}$ & Stop bleeding, chilblain and asthma relive & Jiang et al. (2015) \\
\hline $\begin{array}{l}\text { Rosa xanthina } f \text {. } \\
\text { normalis }\end{array}$ & Effective for qi stagnation, blood stasis & Yu et al. (2007) \\
\hline $\begin{array}{r}\text { Saussurea } \\
\text { japonica }\end{array}$ & $\begin{array}{l}\text { Gingivitis treatment, chills, blood circulation, stasis analgesia, rheumatism, bruises, } \\
\text { leprosy, cold headache, lower back pain }\end{array}$ & Toda et al. (2017) \\
\hline $\begin{array}{r}\text { Scutellaria } \\
\text { viscidula }\end{array}$ & $\begin{array}{l}\text { Roots are source of Huang Qin which is used as a remedy for hepatitis, diarrhea, and } \\
\text { inflammation }\end{array}$ & Wang et al. (2003) \\
\hline Sophora davidii & $\begin{array}{l}\text { Root: cooling blood to stop bleeding stoppage; Fruit: anti-cancer; Leaves: cooling, } \\
\text { detoxification and as insecticide }\end{array}$ & Ohyama et al. (1999) \\
\hline $\begin{array}{l}\text { Thermopsis } \\
\text { lanceolata }\end{array}$ & Relive cough and asthma & Gao et al. (1998) \\
\hline $\begin{array}{l}\text { Ulmus } \\
\text { macrocarpa }\end{array}$ & $\begin{array}{l}\text { Chronic treatment with RBUM exerts antihypertensive effects in SHRs, and its direct } \\
\text { vasorelaxant and antioxidant properties may contribute to reduce elevated blood } \\
\text { pressure, treatment of inflammation, ulcers, cancers, and parasites }\end{array}$ & $\begin{array}{l}\text { Oh et al. (2008) and } \\
\text { Kwon et al. (2011) }\end{array}$ \\
\hline
\end{tabular}

efficient species screening method that could rescue information from nature. In the present study, vegetation surveys have been conducted in a total area of 36 ha across 12 sites and was effective in identifying nine species association that could be used in an agroforestry setting. Ideally, multiple replications per site are needed for assessing vegetation surveys; however, the large size of the studied plots $(10 \mathrm{~m} \times 3000 \mathrm{~m})$ precluded the use of replications. In future studied, we recommend the inclusion of soil and terrain descriptive variable to improve the derived associations resolution. Finally, we advocate the potential of species screening as a first step in designing agroforestry systems that mimics natural settings.

Acknowledgements We thank $\mathrm{T}$ Bin, $\mathrm{Z}$ Zhongmin, $\mathrm{H}$ Mingliang and W Sha for help during the field trip.

Open Access This article is distributed under the terms of the Creative Commons Attribution 4.0 International License (http:// creativecommons.org/licenses/by/4.0/), which permits unrestricted use, distribution, and reproduction in any medium, provided you give appropriate credit to the original author(s) and the source, provide a link to the Creative Commons license, and indicate if changes were made.

\section{References}

Adler PB, HilleRisLambers J (2008) The influence of climate and species composition on the population dynamics of ten prairie forbs. Ecology 89:3049-3060

Amigun B, Musango JK, Stafford W (2011) Biofuels and sustainability in Africa. Renew Sustain Energy Rev 15:1360-1372

Arita HT (2017) Multisite and multi-species measures of overlap, co-occurrence, and co-diversity. Ecography 40:709-718

Assessment ME (2005) A framework for assessment. Island Press, Washington

Bansal S, Harrington CA, Gould PJ, St Clair JB (2015) Climaterelated genetic variation in drought-resistance of Douglasfir (Pseudotsuga menziesii). Glob Chang Biol 21:947-958 
Bettinetti R, Morabito G, Provini A (2000) Phytoplankton assemblage structure and dynamics as indicator [-2pt] of the recent trophic and biological evolution of the western basin of Lake Como (N. Italy). Hydrobiologia 435:177-190

Bi Q, Guan W (2014) Isolation and characterisation of polymorphic genomic SSRs markers for the endangered tree Xanthoceras sorbifolium Bunge. Conserv Genet Resour 6:895-898

Blaser WJ, Sitters J, Hart SP, Edwards PJ, Olde Venterink H (2013) Facilitative or competitive effects of woody plants on understorey vegetation depend on $\mathrm{N}$-fixation, canopy shape and rainfall. J Ecol 101:1598-1603

Briceño VF, Harris-Pascal D, Nicotra AB, Williams E, Ball MC (2014) Variation in snow cover drives differences in frost resistance in seedlings of the alpine herb Aciphylla glacialis. Environ Exp Bot 106:174-181

Callaway RM, Nadkarni NM, Mahall BE (1991) Facilitation and interference of Quercus douglasii on understory productivity in central California. Ecology 72:1484-1499

Chapin FS, Walker LR, Fastie CL, Sharman LC (1994) Mechanisms of primary succession following deglaciation at Glacier Bay, Alaska. Ecol Monogr 64:149-175

Ciğerci İH, Cenkci S, Kargığlu M, Konuk M (2016) Genotoxicity of Thermopsis turcica on Allium cepa L. roots revealed by alkaline comet and random amplified polymorphic DNA assays. Cytotechnology 68:829-838

Dai JQ, Liu ZL, Yang L (2002) Non-glycosidic iridoids from Cymbaria mongolica. Phytochemistry 59:537-542

De Cáceres M, Font X, Oliva F (2008) Assessing species diagnostic value in large data sets: a comparison between phi-coefficient and Ochiai index. J Veg Sci 19:779-788

de Gasper AL, Eisenlohr PV, Salino A (2015) Climate-related variables and geographic distance affect fern species composition across a vegetation gradient in a shrinking hotspot. Plant Ecol Divers 8:25-35

De Padua L, Bunyapraphatsara N, Lemmens R (1999) Plant resources of South-East Asia. Backhuys Publisher, Jakarta

Dice LR (1945) Measures of the amount of ecologic association between species. Ecology 26:297-302

Dick JM, Smith RI, Scott EM (2011) Ecosystem services and associated concepts. Environmetrics 22:598-607

Dohn J, Dembélé F, Karembé M, Moustakas A, Amévor KA, Hanan NP (2013) Tree effects on grass growth in savannas: competition, facilitation and the stress-gradient hypothesis. J Ecol 101:202-209

Dohn J, Augustine DJ, Hanan NP, Ratnam J, Sankaran M (2017) Spatial vegetation patterns and neighborhood competition among woody plants in an East African savanna. Ecology 98:478-488

Dullinger S, Kleinbauer I, Pauli H, Gottfried M, Brooker R, Nagy L, Theurillat JP, Holten J, Abdaladze O, Benito JL (2007) Weak and variable relationships between environmental severity and small-scale co-occurrence in alpine plant communities. J Ecol 95:1284-1295

Dwyer JM, Hobbs RJ, Wainwright CE, Mayfield MM (2015) Climate moderates release from nutrient limitation in natural annual plant communities. Global Ecol Biogeogr 24:549-561

Efferth T, Kaina B (2011) Toxicities by herbal medicines with emphasis to traditional Chinese medicine. Curr Drug Metab 12:989-996
Ekor M (2013) The growing use of herbal medicines: issues relating to adverse reactions and challenges in monitoring safety. Front Pharmacol 4:177

Franco A, Nobel P (1989) Effect of nurse plants on the microhabitat and growth of cacti. J Ecol 77:870-886

Gao W, Li Y, Zhu D (1998) Alkaloids from lanceleaf thermopsis (Thermopsis lanceolata). Chin Tradit Herbal Drugs 29:796-797

Greig-Smith P (1983) Quantitative plant ecology. University of California Press, California

Griffith DM, Veech JA, Marsh CJ (2016) cooccur: Probabilistic species co-occurrence analysis in R. J Stat Softw 69:1-17

Guo LP, Huang LQ, Jiang YX, Zhu YG, Chen BD, Zeng Y, Fu GF, Fu MH (2006) Bioactivity of extracts from rhizome and rhizosphere soil of cultivated Atractylodes Lancea DC. and identification of their allelopathic compounds. Acta Ecol Sin 26:528-535

Guo ZZ, Wu YL, Wang RF, Wang WQ, Liu Y, Zhang XQ, Gao SR, Zhang Y, Wei SL (2014) Distribution patterns of the contents of five active components in taproot and stolon of Glycyrrhiza uralensis. Biol Pharm Bull 37:1253-1258

Harrison P (2005) A socio-economic assessment of sustainable livelihood opportunities for communities of Kuruwitu and Vipingo, Kilifi District, Kenya

Harrison S, Harrison R (2016) Financial models of multispecies agroforestry systems in Fiji and Vanuatu. Promoting sustainable agriculture and agroforestry to replace unproductive land use in Fiji and Vanuatu 8:104

Harrison SR, Avela M, Jesusco J (2009) Agroforestry farming practices of smallholders in Leyte and implications for agroforestry systems design. ACIAR Smallholder Forestry Project, ASEM/2003/052. Improving financial returns to smallholder tree farmers in the Philippines, End-of-Project Workshop. The University of Queensland, pp 111-120

Hubalek Z (1982) Coefficients of association and similarity, based on binary (presence-absence) data: an evaluation. Biol Rev 57:669-689

Jiang H, Zhang Y, Lü E, Wang C (2015) Archaeobotanical evidence of plant utilization in the ancient Turpan of Xinjiang, China: a case study at the Shengjindian cemetery. Veg Hist Archaeobot 24:165-177

Jose S (2009) Agroforestry for ecosystem services and environmental benefits: an overview. Agrofor Syst 76:1-10

Jose S, Gillespie A, Pallardy S (2004) Interspecific interactions in temperate agroforestry. New Vistas in agroforestry. Springer, New York, pp 237-255

Jost L (2007) Partitioning diversity into independent alpha and beta components. Ecology 88:2427-2439

Kenkel NC, Orlóci L (1986) Applying metric and nonmetric multidimensional scaling to ecological studies: some new results. Ecology 67:919-928

Kiers ET, Leakey RR, Izac AM, Heinemann JA, Rosenthal E, Nathan D, Jiggins J (2008) Agriculture at a crossroads. Science-New York then Washington 320:320

Kimura R, Bai L, Fan J, Takayama N, Hinokidani O (2007) Evapo-transpiration estimation over the river basin of the Loess Plateau of China based on remote sensing. J Arid Environ 68:53-65

Koerner SE, Collins SL (2014) Interactive effects of grazing, drought, and fire on grassland plant communities in North America and South Africa. Ecology 95:98-109 
Kuebbing SE, Nuñez MA (2015) Negative, neutral, and positive interactions among nonnative plants: patterns, processes, and management implications. Glob Chang Biol 21:926-934

Kwon JH, Kim SB, Park KH, Lee MW (2011) Antioxidative and anti-inflammatory effects of phenolic compounds from the roots of Ulmus macrocarpa. Arch Pharm Res 34:1459-1466

Lenoir J, Svenning JC (2015) Climate-related range shifts-a global multidimensional synthesis and new research directions. Ecography 38:15-28

Li Y, Xu H, Chen D, Luo T, Mo J, Luo W, Chen H, Jiang Z (2008) Division of ecological species groups and functional groups based on interspecific association- a case study of the tree layer in the tropical lowland rainforest of Jianfenling in Hainan Island, China. Front For China 3:407-415

Liu Y, Huo N, Dong L, Wang Y, Zhang S, Young HA, Gu YQ (2013) Complete chloroplast genome sequences of Mongolia medicine Artemisia frigida and phylogenetic relationships with other plants. PLoS ONE 8:e57533

Liu Y, Müller K, El-Kassaby YA, Kermode AR (2015) Changes in hormone flux and signaling in white spruce (Picea glauca) seeds during the transition from dormancy to germination in response to temperature cues. BMC Plant Biol 15:292

Ma CM, Nakamura N, Nawawi A, Hattori M, Cai S (2004) A novel protoilludane sesquiterpene from the wood of Xanthoceras sorbifolia. Chin Chem Lett 15:65-67

Maher BA (2016) Palaeoclimatic records of the loess/palaeosol sequences of the Chinese Loess Plateau. Quat Sci Rev $154: 23-84$

Malanson GP (2017) Interactions and constraints in model species response to environmental heteroscedasticity. J Theor Biol 419:343-349

Malanson GP, Zimmerman DL, Kinney M, Fagre DB (2017) Relations of alpine plant communities across environmental gradients: multilevel versus multiscale analyses. Ann Assoc Am Geogr 107:41-53

Masaki T, Suzuki W, Niiyama K, Iida S, Tanaka H, Nakashizuka T (1992) Community structure of a species-rich temperate forest, Ogawa Forest Reserve, central Japan. Vegetatio 98:97-111

Mitchell RJ, Flanagan RJ, Brown BJ, Waser NM, Karron JD (2009) New frontiers in competition for pollination. Ann Bot 103:1403-1413

Oh KS, Ryu SY, Oh BK, Seo HW, Kim YS, Lee BH (2008) Antihypertensive, vasorelaxant, and antioxidant effect of root bark of Ulmus macrocarpa. Biol Pharm Bull 31:2090

Ohyama M, Tanaka T, Ito T, Iinuma M, Bastow KF, Lee KH (1999) Antitumor agents 200.1 cytotoxicity of naturally occurring resveratrol oligomers and their acetate derivatives. Bioorg Med Chem Lett 9:3057-3060

Oksanen J, Blanchet FG, Kindt R, Legendre P, Minchin PR, O'hara R, Simpson GL, Solymos P, Stevens MHH, Wagner H (2013) Package 'vegan'. Community ecology package, version 2

Pathare VS, Crous KY, Cooke J, Creek D, Ghannoum O, Ellsworth DS (2017) Water availability affects seasonal $\mathrm{CO}_{2^{-}}$ induced photosynthetic enhancement in herbaceous species in a periodically dry woodland. Glob Chang Biol 23:5164-5178

Pugnaire FI, Haase P, Puigdefabregas J (1996) Facilitation between higher plant species in a semiarid environment. Ecology 77:1420-1426

Riginos C (2009) Grass competition suppresses savanna tree growth across multiple demographic stages. Ecology 90:335-340

Ruan CJ, Yan R, Wang BX, Mopper S, Guan WK, Zhang J (2017) The importance of yellow horn (Xanthoceras sorbifolia) for restoration of arid habitats and production of bioactive seed oils. Ecol Eng 99:504-512

Schmidhuber J, Tubiello FN (2007) Global food security under climate change. PNAS 104:19703-19708

Sheela M, Ramakrishna M, Salimath BP (2006) Angiogenic and proliferative effects of the cytokine VEGF in Ehrlich ascites tumor cells is inhibited by Glycyrrhiza glabra. Int Immunopharmacol 6:494-498

Š́mová I, Violle C, Kraft NJ, Storch D, Svenning JC, Boyle B, Donoghue JC, Jørgensen P, McGill BJ, Morueta-Holme N (2015) Shifts in trait means and variances in North American tree assemblages: species richness patterns are loosely related to the functional space. Ecography 38:649-658

Simpson GG (1943) Mammals and the nature of continents. Am J Sci 241:1-31

Song MK, Um JY, Jang HJ, Lee BC (2012) Beneficial effect of dietary Ephedra sinica on obesity and glucose intolerance in high-fat diet-fed mice. Exp Ther Med 3:707-712

Tamang BG, Magliozzi JO, Maroof MS, Fukao T (2014) Physiological and transcriptomic characterization of submergence and reoxygenation responses in soybean seedlings. Plant, Cell Environ 37:2350-2365

Tan A (2012) Advances in modern research on the medicinal herbs in Mongolia. Northern Pharm Sci 9:33-34

Tilman D, Reich PB, Knops J, Wedin D, Mielke T, Lehman C (2001) Diversity and productivity in a long-term grassland experiment. Science 294:843-845

Toda Y, Shigemori H, Ueda J, Miyamoto K (2017) Isolation and identification of polar auxin transport inhibitors from Saussurea costus and Atractylodes japonica. Acta Agrobotanica 70:1-8

Tokeshi M (1993) Species abundance patterns and community structure. Adv Ecol Res 24:111-186

Wang HY, Xiao LH, Liu L, Xu SX (2003) Studies on chemical constituents of the roots of Scutellaria viscidula. J Shenyang Pharma University. 20:329-335

Wang Z, Dong Y, Wu G, Li M (2012) Microscopic identification of Cymbaria Powder. J Baotou Med Coll 28:7-8

Wang T, Wang G, Innes J, Nitschke C, Kang H (2016) Climatic niche models and their consensus projections for future climates for four major forest tree species in the AsiaPacific region. For Ecol Manage 360:357-366

Wei M, Zhuge YP, Lou YH, Liu F, Liu AH (2010) Effects of fertilization on Xanthoceras sorbifolia Bunge growth and soil enzyme activities. J Soil Water Conserv 2:051

Wilson JB, Sykes MT, Peet RK (1995) Time and space in the community structure of a species-rich limestone grassland. J Veg Sci 6:729-740 
Xin Z, Yu X, Li Q, Lu X (2011) Spatiotemporal variation in rainfall erosivity on the Chinese Loess Plateau during the period 1956-2008. Reg Environ Change 11:149-159

Yamori W, Hikosaka K, Way DA (2014) Temperature response of photosynthesis in $\mathrm{C} 3, \mathrm{C} 4$, and CAM plants: temperature acclimation and temperature adaptation. Photosynth Res 119:101-117

Yang Q, Zhu G, Hong D, Wu Z, Raven PH (2005) World's largest flora completed. Science 309:2163

Yang LQ, Zeng-Chun LI, Xiao DH (2006) Study on chemical constituents of volatile oil from Mongolian medicine Artemisia Frigida Willd. J Inner Mongolia University for Nationalities 21:275-278

Yeo D, Hwang J, Kim J, Youn HJ, Lee HJ (2018) The aqueous extract from Artemisia capillaris inhibits acute gastric mucosal injury by inhibition of ROS and NF-kB. Biomed Pharmacother 99:681-687

Yu X, Fan X, Zeng Y, Yang J (2007) Study on methods for extraction of genomic DNA from Rosa xanthina Lindl. Leaves. Acta Agric Boreali-Occidentalis Sin 4:066
Zhang J (2013) spaa: SPecies Association Analysis. R package version 0.2.1. https://CRAN.R-project.org/package = spaa

Zhang S, Zu YG, Fu YJ, Luo M, Zhang DY, Efferth T (2010) Rapid microwave-assisted transesterification of yellow horn oil to biodiesel using a heteropolyacid solid catalyst. Bioresour Technol 101:931-936

Zhao W, Deng AJ, Du GH, Zhang JL, Li ZH, Qin HL (2009) Chemical constituents of the stems of Ephedra sinica. J Asian Nat Prod Res 11:168-171

Zhou Q, Liu G (2012) The embryology of Xanthoceras sorbifolium and its phylogenetic implications. Plant Syst Evol 298:457-468

Zhou L, Wang N-J, Zhang L-N (2012) Effect of PEG treatment on seed germination and growth of seedlings of Xanthoceras sorbifolia. Acta Bot Boreali-Occidentalia Sinica 11:022 